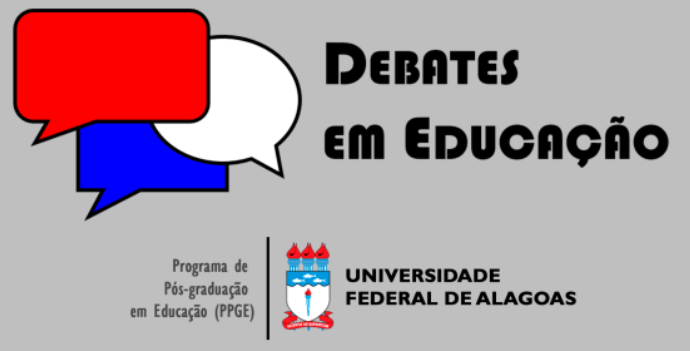

ISSN Eletrônico 2175-6600

Vol. 12 | N. 28 | Set./Dez. | 2020

Maria do Socorro Aguiar Oliveira

Cavalcante

9 iD

Universidade Federal de Alagoas (UFAL) mdosaoc@gmail.com

José Edson Ferreira Lima

9 iD

Universidade Federal de Alagoas (UFAL) edsonlimaverba@hotmail.com

\section{O TRABALHO DOCENTE NO DISCURSO MIDIÁTICO: SENTIDOS QUE RETORNAM*}

\section{RESUMO}

Este trabalho integra o grupo de estudos do discurso e ontologia - GEDON da Faculdade de Letras da Universidade Federal de Alagoas e tem por objetivo analisar discursos materializados na mídia escrita, acerca do trabalho docente. A partir do entendimento de que o discurso é práxis humana que só pode ser compreendida a partir do entendimento das contradições sociais que possibilitam sua objetivação, buscamos desvelar as condições de produção que possibilitaram o surgimento de discursos acerca do trabalho docente e a memória que retorna produzindo efeitos de sentido que contribuem para a reprodução da visão de trabalho docente como sacerdócio, culpabilizando os/as professores/as pelo fraco desempenho das escolas públicas nos exames nacionais. Para tanto, utilizaremos os pressupostos teórico metodológicos da Análise do Discurso pecheutiana, acrescendo uma interlocução com Volóchinov e Lukács. A partir desses pressupostos, analisaremos as determinações ideológicas produtoras de sentido. Essa perspectiva teórica possibilita o desvelamento das contradições e embates ideológicos que determinam os efeitos de sentido que sustentam as materialidades discursivas.

Palavras-chave: Trabalho docente. Mídia. Discurso. Sentido.

\section{TEACHING WORK IN MEDIA DISCOURSE: MEANINGS THAT RETURN}

\begin{abstract}
This paper integrates the group of studies of discourse and ontology - GEDON of the Faculty of Letter of the Federal University of Alagoas and aims to analyze the materialized discourse in written media, about teaching work. Starting from the perspective that the speech is human praxis that can only be understood from the understanding of the social contradictions that enable its objectivation, we seek to unveil the conditions of production that allows the emergence of discourse about the teaching work and the memory that returns producing effects of meanings that contribute to the reproduction of the view of teaching work as a priesthood, blaming teacher for the poor performance of public schools in national exams. For this, we will use the theoretical methodological assumption of Pecheut's Discourse Analysis, adding a dialogue with Volóchinov and Lukács. From these assumptions, we will analyze the ideological determinations that produce meanings. This theoretical perspective makes it possible to unveil the ideological contradictions and clashes that determine the effects of meaning that support the discursive materialities.
\end{abstract}

Keywords: Teaching work. Media. Discourse. Memory.

Submetido em: 30/03/2020

Aceito em: 01/06/2020

Ahead of print em: 08/07/2020

Publicado em: 18/08/2020

do http://dx.doi.org/10.28998/2 I75-6600.2020v I 2n28p365-382 


\section{INTRODUÇÃO}

presente trabalho tem como objetivo geral contribuir para a discussão sobre o papel do professor no contexto educacional brasileiro. De forma específica, a partir do entendimento de que o discurso é práxis humana que só pode ser compreendida a partir do entendimento das contradições sociais que possibilitam sua objetivação, buscamos desvelar as condições de produção que possibilitaram o surgimento do discurso acerca do trabalho docente. Analisaremos também as determinações ideológicas produtoras de sentido e a memória que retorna, produzindo efeitos que contribuem para a reprodução da visão de trabalho docente como sacerdócio, culpabilizando os/as professores/as pelo fraco desempenho das escolas públicas nos exames nacionais. Esse discurso sobre o papel do professor encontra-se arraigado na formação social brasileira, refletido no texto jornalístico e tem profundas raízes históricas, como não poderia deixar de ser. Segundo Voese (1997, p. 16),

[...] o discurso sempre tem uma dimensão histórica. E abandonar a noção de História [...] exclui a ideia de que o discurso tem relação com a ideologia: ele seria, então, neutro, como se não tivesse ligado a um jogo de poder e se constituísse livre de qualquer determinação de uma sociedade que abriga em sua formação conflitos entre classes, grupos e indivíduos. Seria negar que o que se dá no nível social perpassa o discurso e se inscreve na sua materialidade.

É por essa intrínseca relação entre Discurso e História que se faz imprescindível revisitar, ainda que de forma breve, como se constituiu historicamente a profissão docente no Brasil, como forma de buscar, a gênese do discurso da docência como missão e dever sagrado, para, em momento posterior, compreender as diversas imbricações que esse discurso assume no contexto atual e no texto jornalístico opinativo.

No percurso discursivo da profissão docente, sentidos foram-se embrenhando uns nos outros, alguns se cristalizando, outros morrendo ou se transformando. Estereótipos que definem o que é ser professor, na atualidade foram constituídos historicamente, atravessados pela ideologia e materializados na língua. Assim, mesmo aquelas construções ideológico-discursivas mais antigas podem vir à tona, retomados da memória discursiva por meio do interdiscurso, estabilizando-se no intradiscurso, ainda que de forma contraditória a outros sentidos que circulam concomitantemente na sociedade.

O presente artigo será desenvolvido levando em consideração o seguinte percurso. Inicia, tecendo considerações sobre as fases da profissão docente no Brasil, começando pelo período colonial e imperial, passando pelo início do período republicano e chegando à atual reestruturação produtiva do Capitalismo. Em seguida, apresentamos a ancoragem teórica que utilizaremos em nossa análise - os pressupostos teórico-metodológicos da Análise do Discurso pecheutiana acrescendo uma interlocução com Volóchinov (2017) e Lukács(20 I3) -. A partir desses pressupostos, analisamos as determinações ideológicas produtoras de sentido, em sequências discursivas dos editoriais: "Desaprendizado Real", da Gazeta de Alagoas, e 
"Além do Corporativismo", do jornal "O Globo" (23 de setembro de 2013). Esses dois jornais foram escolhidos por tratarem do mesmo tema, em espaços/tempos diferentes - Alagoas, 20 I0; Rio de Janeiro, 2013. 1

A perspectiva teórica adotada possibilita o desvelamento das contradições e embates ideológicos que determinam os efeitos de sentido sustentadores das materialidades analisadas. Permite-nos também observar que o discurso materializado nos editoriais corresponde à formação ideológica do Capital, com uma formação discursiva conservadora, a qual se caracteriza por recriminar a greve do magistério e rememorar o discurso da missão/vocação do professor.

\section{PROFESSOR “SACERDOTE”: UM BREVE PERCURSO HISTÓRICO}

No Brasil colonial, a atividade docente foi empreendida inicialmente, por religiosos e leigos, caracterizando-se como atividade não especializada, secundária. De acordo com Costa (1995, p. 76), "até o final do século XVIII, a escola é dominada pela igreja e as tarefas do mestre compreendem, prioritariamente, obrigações religiosas e comunitárias, ficando em segundo plano as ocupações de caráter educativo". Coube aos jesuítas o papel de "educadores" dos povos indígenas por meio da catequese e, posteriormente, também dos demais habitantes do novo mundo.

Esse período de gênese da educação brasileira foi especialmente determinante na formação da identidade docente nacional e, principalmente, na composição do discurso sobre o papel e a natureza do professor e do seu trabalho. Nesse sentido, diz Azevedo (1958, p. 9):

[...] a vinda dos padres jesuítas, em 1549, não só marca o início da história da educação no Brasil, mas inaugura a primeira fase, a mais longa dessa história, e, certamente a mais importante pelo vulto da obra realizada e, sobretudo, pelas consequências que dela resultaram para nossa cultura e civilização.

Por conseguinte, a estreita relação entre o magistério e a atividade religiosa, como vimos, fazia com que professor e clérigo estivessem concentrados numa só figura. A tarefa de catequizar e suas implicações de abnegação e sacralidade coincidiam, a um só tempo, com a instrução básica, com o ensino, com a docência. Esse quadro compõe-se ainda dos aspectos filantrópico e caridoso de que se revestia a atuação educativa jesuítica. Shigunov Neto \& Maciel (2008, p. 172), a respeito da atuação educacional dos jesuítas afirmam: "seu papel, na sociedade portuguesa da época foi fundamental, pois cabia a eles propiciar

\footnotetext{
' Este artigo é parte de uma dissertação de mestrado, defendida em 20 I8. No texto original, foram examinados editoriais dos jornais Gazeta de Alagoas, O Globo, Folha de São Paulo, Gazeta do Povo e Zero Hora, pulicados entre os anos de 2010 e 2015 , os quais abordam a temática das greves do magistério e da escassez de jovens universitários dispostos a exercer a docência. Dadas as limitações deste artigo, analisaremos aqui, apenas dois editoriais - da Gazeta de Alagoas e do jornal O Globo.
} 
as condições necessárias para educar os grupos sociais menos favorecidos da população. Portanto, sua obra tornava-se uma atividade de caridade."

Desse modo, a rede de sentidos ligados à docência, na gênese da educação brasileira, vai se caracterizar pela presença indelével da associação da sacralidade, e seus consequentes desdobramentos de abnegação e filantropia. Essas construções discursivas serão ressignificadas ao longo do tempo, de acordo com as mudanças na formação social brasileira.

Afirma Saviani (2004) que é somente após a promulgação do Ato Adicional de I 834 que as escolas normais começam a ser estabelecidas. Principia-se, assim, a institucionalização da formação do magistério, nas décadas de 30 e 40 do século XIX, período que coincide precisamente com a consolidação do nosso Estado Nacional.

É a criação das escolas normais que, segundo Melo (20I I) demarca uma mudança sociológica no corpo docente primário verificada no século XIX, o que estabelece condições para o surgimento das primeiras associações profissionais. Surge, assim, uma relativa consciência de grupo profissional e autonomia em relação ao Estado. Os docentes, a escola, a educação passam a gozar de grande prestígio social, encarnando os anseios de progresso, promoção social, sendo o professor o iluminado agente desses conceitos. O regenerador da sociedade é, portanto, mais um dos sentidos que compuseram/compõem o discurso sobre o professor.

aspecto seguinte dessa construção histórica é o processo de feminização do magistério. A entrada das mulheres no exercício do magistério, no Brasil, se dá ao longo do século XIX. No início, de forma lenta, porém, depois, intensivamente.

\section{I A feminização do magistério e a educação nos primeiros anos da república}

As mudanças no campo político do final do século XIX que trouxeram a república ao Brasil consolidaram a feminização do magistério, já iniciada anteriormente. Mais que isso: houve um significativo aumento da presença das mulheres nas escolas. Esse processo, que trouxe predominantemente as mulheres ao meio escolar, é explicado na citação de Almeida (2006, p. 136) que segue.

\footnotetext{
A feminização do magistério primário que ocorreu em Portugal e no Brasil em fins do século XIX aconteceu num momento em que o campo educacional se expandiu em termos quantitativos. A mão de obra feminina na educação principiou a revelar-se necessária, principalmente tendo em vista os impedimentos morais dos professores de educar as meninas e a recusa da sociedade à coeducação dos sexos considerada perigosa do ponto de vista moral. Quando o poder público abriu a possibilidade de as mulheres poderem ensinar e com isso exercer uma profissão remunerada, produziu-se uma grande demanda pela profissão de professora. $\bigcirc$ discurso ideológico que acompanhou essa demanda construiu uma série de argumentações que alocavam às mulheres um melhor desempenho profissional na educação, derivado do fato de a docência estar ligada às ideias de domesticidade e maternidade. Essa ideologia teve o poder de reforçar os estereótipos e a segregação sexual, pois se entendia que cuidar de crianças e educar era missão feminina, por isso o magistério se revelava como seu lugar por excelência. Portanto, as relações
} 
patriarcais e econômicas que reestruturavam a sociedade em finais do século XIX tiveram grande importância no processo de feminização da profissão.

A exaltação à arte de ensinar mantém-se, como no período anterior, porém, há um deslizamento de sentidos, os quais passam da sacralidade religiosa à do progresso e da moralidade. Atribuía-se à escola e ao magistério, o poder de transformar, por si só, a realidade social. Em outras palavras, a rede de sentidos religiosa dá lugar à do ideário liberal, a qual é, em certa medida, a manutenção e extensão da primeira, isto é, os sentidos sobre o papel do professor são ressignificados, ao mesmo tempo em que a docência mantém sua aura de iluminação, abnegação e domesticação, agora sob o viés do discurso liberal. Muda a visão de docência que remete aos antigos mestres religiosos, cujo perfil se formava pela missão extraordinária, a vocação, a doação, intermediada por uma visão do/a educador/a como salvador(a) da pátria e dos indivíduos, não mais de suas almas, mas agora, muito mais de seus intelectos, de sua formação para se adaptar à sociedade. Conforme Louro (2008, p. 97),

[...] a representação do magistério é, então, transformada. As professoras são compreendidas como mães espirituais - cada aluno ou aluna deve ser percebido/a como seu próprio filho ou filha. De algum modo, as marcas religiosas da profissão permanecem, mas são reinterpretadas e, sob novos discursos e novos símbolos, mantém-se o caráter de doação e de entrega que já se associava à atividade docente. $\bigcirc$ magistério precisava ser compreendido, então, como uma atividade de amor, de entrega e doação, uma extensão da maternidade para a qual acorreria quem tivesse vocação.

Saviani (2004, p 22) explicita, em linhas gerais, como o ideário liberal republicano desse momento histórico pensava a educação, concepção que teve como reflexo o já demonstrado aprofundamento da feminização no ensino primário. "Emergia a tendência a considerar a escola como chave para solução dos demais problemas enfrentados pela sociedade, dando origem à ideia da escola redentora da humanidade".

É importante frisar que o reconhecimento social do trabalho docente, existente até então, nem sempre era concretizado em melhores condições de vida e de trabalho. Na verdade, o discurso da vocação, da missão e da maternidade já funcionava de forma plena para atender aos interesses dominantes, tanto por promover uma educação domesticadora, quanto por amortecer quaisquer insurgências da classe docente, para quem a resiliência às intempéries e às precárias condições de trabalho era parte intrínseca da missão de educar.

No que diz respeito ao sistema pedagógico, adotou-se, de maneira ardorosa, o método posteriormente denominado como tradicional, baseado em elementos como a repetição, a disciplina, o formalismo, e a autoridade do professor, por intermédio da qual se aplicavam prêmios, punições e promovia-se o sentimento de mérito (SAVIANI, 2004).

Esse último aspecto é especialmente relevante para nossa discussão e análise, já que corresponde ao discurso sobre o professor que permeava a sociedade da época e está diretamente ligado à valorização da docência a que se propunha a república recém- estabelecida. A centralidade da autoridade do professor era um dos principais eixos sobre os quais se assentava a prática pedagógica da época e era como já 
dissemos, ao mesmo tempo, resultante da ressignificação e retomada de sentidos sobre o magistério que circularam nos três primeiros séculos de nossa formação social.

\subsection{Crescimento, precarização e reconfiguração do trabalho docente.}

período de efervescência teórica e relativos avanços nas concepções de educação foram, paulatinamente, sendo suplantados com o passar dos anos, especialmente após a concretização do Golpe Militar de 1964, o qual trouxe uma reorientação para o ensino do país. Pautado pela repressão, o Estado editou políticas e práticas que, em linhas gerais, redundaram no tecnicismo; na expansão quantitativa da escola pública de $1^{\circ}$ e $2^{\circ}$ graus às custas do rebaixamento da sua qualidade; no cerceamento e controle das atividades acadêmicas no interior das universidades e na expansão da iniciativa privada no ensino superior. (FERREIRA JÚNIOR \& BITTAR, 2006).

Essa conjuntura foi o principal responsável por uma mudança drástica na identidade da classe docente brasileira. Os autores supracitados denominaram esse processo como proletarização do magistério brasileiro. Em síntese, esse processo ocorreu justamente pelo aumento quantitativo abrupto e precário da oferta de educação básica a partir da década de 1970; pela redução da remuneração recebida pelos professores, ao mesmo tempo em era exigida uma formação mais célere para o exercício da profissão. Tais fatos afastaram os profissionais mais preparados e de classes mais abastadas, ao tempo em que atraíram para a carreira, outro tipo de trabalhador com menor vivência e preparo e em número maior que os antigos professores. Segundo Ferreira Junior \& Bittar (2006, p.161): "a combinação entre crescimento quantitativo, formação acelerada e arrocho salarial deteriorou ainda mais as condições de vida e de trabalho do professorado nacional do ensino básico".

Por conseguinte, os autores explicam que o professorado passou a conviver, de um lado, com os remanescentes do período de ouro da educação, vendo suas condições de vida e de trabalho definharem e de outro com uma massa de trabalhadores das classes menos favorecidas que viam a carreira como o clímax de suas trajetórias. Tal proletarização do magistério brasileiro aproximou os professores dos demais trabalhadores pelas condições de precariedade semelhantes. Esse processo levaria, por fim, à gênese do movimento sindical docente. (FERREIRA JUNIOR \& BITTAR (2006).

Perseguindo o nosso fio de discussão, que gira em torno da construção histórico-ideológica da profissão docente, interessa-nos, de maneira especial, constatar que as mudanças ocorridas na realidade desse momento histórico de nossa formação social, as quais trouxeram a reboque essa "proletarização do magistério" acabaram por trazer novos sentidos ao papel do professor. Sem dúvida, passa a haver uma inevitável corrosão do antigo prestígio dado à carreira, mudança que é proporcional à queda da remuneração e à fuga dos antigos profissionais mais bem qualificados. Essa nova fase trouxe ao docente 
sua consciência de coletividade para a luta. Entretanto, os sentidos de sacerdócio e missão já construídos anteriormente permanecem, provocando embates e ressignificações.

O resultado desse amálgama de trabalhadores da educação aliado às precariedades, traria nos anos seguintes, uma série de greves, mobilizações reflexões, as quais, com o fim da ditadura militar em 1985 , deixaram importantes contribuições para a Constituição de 1988.

\subsection{Neoliberalismo e reestruturação da atividade docente}

A chegada da década de 1990 e a identidade do trabalho dos professores construída no período anterior de luta pela redemocratização será assim retratada por Melo (20 I I, p. I45):

[...] ao longo da década de 1990, essa identidade sofrerá fraturas em meio às mudanças ocorridas no mundo do trabalho que determinarão formas cada vez mais precárias de acesso aos empregos e a destruição de grande parte dos direitos trabalhistas. Nesse contexto, o discurso neoliberal enfatiza o individualismo, o empreendedorismo do trabalhador na busca de melhoria de seu status profissional. A identidade de classe dos professores será atingida pela crise da organização sindical docente expressa nos seguintes indicadores: I) esgotamento das greves; 2) ausência de diálogo com a população usuária das escolas públicas; 3) divergências político-ideológicas nas entidades; 4) distância entre as lideranças das associações/sindicatos e o professorado.

Nessa conjuntura, os aspectos subjetivos e as capacidades cognitivas de adaptação comporão o quadro de novas exigências, apontando para um caminho de apreensão da subjetividade do trabalhador. De uma parte, os modelos de organização exigem estabilidade e envolvimento dos indivíduos no processo de trabalho (autonomia, iniciativa, responsabilidade, comunicação, etc.) e, de outra, os vínculos empregatícios tornam-se cada vez mais precários e instáveis. Esse apelo ao subjetivismo e ao envolvimento do trabalhador não o poupa de sofrer, ao mesmo tempo, a ameaça permanente de precarização e fragilização do seu emprego e do seu salário. Tais fatores são responsáveis por um constante aumento de sérios problemas de saúde dos trabalhadores. (DRUCK, 2012).

Ao mesmo tempo, o discurso sobre a importância do magistério apresenta-se mais uma vez, desta feita, sob a égide da necessidade de promover a adaptação dos educandos às novas necessidades da sociedade, concebida como "sociedade do conhecimento", "sociedade da informação", como afirma Melo (2011, p. 130):

[...] filiado a esse discurso, o discurso oficial busca redefinir as formas de atuação do educador na escola e na sala de aula, apresentando "novas" orientações para a formação centradas na epistemologia da prática. Será então desenvolvida uma reforma curricular centrada na valorização da prática, pois enfatiza-se que, ao longo da história educacional, o trabalho pedagógico foi marcado por uma dimensão teórica que não contribuiu para adequar a escola às exigências sociais.

Eficiência e adaptação passam, pois a serem as palavras de ordem em um sistema educacional que se propõe a servir ao mercado, nessa visão utilitarista da educação e do próprio educador, denominado profissional da educação na nova LDB (1996). O processo de precarização iniciado na ditadura militar 
precisará também se adaptar. A autonomia que lhe é atribuída vai apenas culminar em acréscimo de mais atividades. Aprofunda-se, desse modo, a precarização do magistério, na medida em que o professor precisará se tornar um profissional multiforme, com uma remuneração insuficiente e uma carga de trabalho avolumada.

Às condições de trabalho e econômicas ruins soma-se a consolidação da perda do antigo prestígio da profissão, processo que, como vimos anteriormente, já se havia iniciado a partir do Golpe Militar. Na conjuntura neoliberal introduzida nos anos 90 , o professor passa ao status de mediador, despido da robusta autoridade de outros tempos e investido de um reconhecimento que apenas aumenta a carga de trabalho e de responsabilidades. Tal quadro promove ainda mais o afastamento dos jovens mais qualificados da profissão.

Por fim, nesse breve percurso histórico-ideológico que fizemos, buscamos não perder o fio dos diversos discursos a respeito do professor que emergiram das/nas condições históricas pelas quais o Brasil passou desde o início de sua colonização. A importância da figura do professor foi sempre ressaltada: inicialmente, sob o aspecto religioso como sacerdócio; depois como missão progressista; em seguida, como agente de uma expansão e, por fim, como mediador de uma educação para adaptação às novas exigências sociais. Entretanto, é fundamental constatar que a práxis de um período não suplanta a outra. Ocorre assim a constante ressignificação dos sentidos da docência que possibilita a retomada de construções já cristalizadas pela história e pela ideologia. Dito de outra forma, não se pode falar em sentidos substituídos por outros. A riqueza dessa construção emergirá diante de nossos olhos constantemente com suas reconfigurações.

Para desvelar as contradições e embates ideológicos que determinam os efeitos de sentido de materialidades que sustentam o discurso acerca do papel do professor, lançamos mão dos pressupostos teórico-metodológicos da Análise do Discurso pecheutiana, ancorada no materialismo histórico dialético.

\section{ANÁLISE DO DISCURSO: ALGUMAS CONSIDERAÇÕES}

A Análise do Discurso (AD) de linha francesa a que nos filiamos é concebida como um campo de estudos surgido na década de 60, que teve sua gênese associada a uma prática escolar francesa: a da interpretação de textos. Com o fracasso do socialismo soviético e as nítidas contradições do capitalismo, era preciso rever os conceitos do marxismo e propor uma releitura dele. Diversos autores dedicavam-se a discussões que gravitavam em torno do Estruturalismo e do Marxismo, em especial Michel Pêcheux, considerado o maior expoente e fundador da vertente da AD ancorada no Materialismo Histórico. $O$ engajamento político desse e de outros intelectuais, especialmente na França, era evidente. Segundo Carneiro (2008, p. 16): "[... ] a Análise do Discurso não foi projetada para ser apenas um simples campo 
de estudo, mas para ser um instrumento de intervenção política. [...] Dentre outras coisas, pretendia-se desmascarar as verdades construídas por políticos oportunistas."

Dessa forma, a episteme da Análise do Discurso origina-se, a priori, do entrecruzamento das três áreas do conhecimento (materialismo histórico, linguística, e teoria do discurso). Como atesta, ainda, Gregolin (200I), esses campos disciplinares articulados para a constituição teórica da AD são atravessados por uma teoria subjetiva de ordem psicanalítica, que traz o inconsciente para o interior de suas reflexões.

Pêcheux coloca então, em cena, o discurso como objeto de análise. Esse elemento é diferente tanto da língua, quanto da fala. Ele não é o mesmo que transmissão de informação, nem é um simples ato do dizer. Sua natureza é muito mais complexa: Segundo Ferreira (2005, p. I3), "É no discurso, precisamente, que se concentram, se intrincam e se confundem, como um verdadeiro nó, as questões relativas à língua, à história e ao sujeito". (Sic).

Segundo Florencio et. al. (2009, p. 64), na perspectiva da AD pecheutiana, o discurso é entendido como práxis, uma vez que "é produzido nas relações sociais, em determinado momento histórico, trazendo em si o histórico e o ideológico, próprios a essas relações". Essa afirmação encontra respaldo em Pêcheux (1988, p. |45) quando afirma que, "no discurso, o sentido está na relação entre sujeitos e não unicamente nas palavras". Nessa perspectiva, discurso não é o texto, tampouco o simples pronunciamento público de qualquer ordem, mas sim práticas sociais que se materializam na língua(gem).

Por conseguinte, o analista deve reportar-se a uma materialidade linguística, compreendida como materialização de discursos, cuja compreensão e/ou explicação faz com que recorramos a aparatos teóricos fora da Linguística, sem, no entanto, deixá-la de lado.

Ocorre que, nessa ótica pecheutiana, o sentido não está óbvio ou transparente, uma vez que é preciso considerar a opacidade da materialidade aí presente. Em consequência, toda descrição, conforme afirma Pêcheux (1983, p. 53), "está exposta ao equívoco da língua: todo enunciado é intrinsecamente suscetível de tornar-se outro, diferente de si mesmo, se deslocar discursivamente de seu sentido para derivar para outro".

Diante desses pressupostos da instituição da Análise do Discurso, verifica-se o espaço do contraditório nessa disciplina de entremeio (ORLANDI, 2008), pois a língua tem autonomia relativa e é uma entrada para a materialidade do discurso. É aí que se observa a determinação histórica dos sentidos. Nessa perspectiva, portanto, o analista do discurso deve considerar sempre as Condições de Produção (CP) do discurso, tanto estritas quanto amplas. Isso implica dizer que, para compreender o discurso, é preciso levar em conta o contexto imediato de sua formulação - condições estritas - e o processo sócio histórico e ideológico da conjuntura que possibilitou sua irrupção - condições amplas - que determinam/possibilitam a produção de discursos, uma vez que, segundo Florêncio et al (2016, p. 67): "Os sujeitos do discurso interagem na constituição das relações discursivas, trazendo elementos que 
derivam da história, da sociedade e de suas contradições ideológicas". Assim, não se pode falar de sujeito e de discurso sem falar de ideologia. Conforme afirmam Cavalcante e Machado (20 I7, p. 38),

[...] esse termo tem sido tratado nas mais diversas acepções: como sinônimo de atividade científica; [...] como ilusão de sentidos; como falsa consciência e, ainda, como complexo da vida social que tem por função orientar a práxis humana. Isso se deve [...] a sua capacidade de mobilizar investimentos teóricos que possibilitam abordagens, a partir de diferentes perspectivas: gnosiológica e ontológica. A opção por uma ou outra perspectiva conduzirá o pesquisador para diferentes formas de abordagem do real e para diferentes procedimentos metodológicos.

A compreensão do fenômeno ideológico que adotamos neste trabalho tem por base o conceito ontológico-prático de ideologia formulado por Lukács (2013), para quem a produção e reprodução da existência social humana ocorrem a partir de posições teleológicas. Na perspectiva lukacsiana, somente o ser humano é capaz de estabelecer um fim para seus atos e, ao mesmo tempo, antever os resultados. A partir daí, o autor definirá a teleologia primária como aquela em que o homem atua sobre a natureza, sendo a secundária a ação dos homens sobre outros homens. Por conseguinte, de acordo com Florêncio et.al. (2009, p. 37), "é das posições teleológicas secundárias nas quais se realiza a 'prévia-ideação da prática social dos homens', no sentido de infuenciar outros homens a assumirem posições, que surge a ideologia".

Daí resulta que a ideologia tem um nascedouro ontológico, ligado ao fundante do ser social que é o trabalho e, ao mesmo tempo, projetada de forma material e prática, como apaziguadora dos conflitos. Florêncio et.al. (idem) dizem que "essa concepção de ideologia apoia-se na noção de homem como um ser prático que reage às demandas postas pela realidade objetiva, um ser que dá respostas a necessidades determinadas". Torna-se, portanto, mediação nos conflitos de interesse gerados no campo econômico, que são enfrentados mediante a criação de complexos sociais ideológicos, com a função de regular as relações entre os homens, em resposta a necessidades da totalidade social. A ideologia com essa função, tanto em forma ideal quanto em forma prática, pode agir no sentido de manter ou de modificar aspectos da realidade social, retroagindo sobre os processos socioeconômicos em curso. A partir dessa perspectiva, o entendimento de sujeito adotado pela AD, ancorada no Materialismo Histórico Dialético, é, antes de tudo, social, ideológico e não individual e pode ser caracterizado de maneira tríplice, conforme afirma Carneiro (2008, p. 20):

[...] um ente histórico, social e descentrado. Descentrado, pois é cindido pela ideologia e pelo inconsciente. Histórico, porque não está alienado do mundo que o cerca. Social, porque não é o indivíduo isolado, mas aquele apreendido num espaço coletivo.

Para Cavalcante et. al. (2009, p. 45), "esse sujeito será constituído através das práticas sociais e da ideologia que darão as bases do seu complexo psíquico". Ou seja, o processo de constitução dos sujeitos ocorre através de processos de identificação com formas específicas de ideologia que põem em jogo práticas associadas às relações de classe. Essas formas específicas são denominadas Formações Ideológicas que, segundo Cavalcante (2009, p. 42): "não são atos individuais; organizam-se em formações sociais que 
mantêm entre si relações antagônicas de aliança e de dominação” ou ainda como diz Haroche et. al. ( 197 | , p. 102): "um conjunto complexo de atitudes e representações que nem são individuais nem universais, mas dizem respeito às posições de classes em conflito".

Assim, ao analisar um discurso, o analista deve recorrer, inicialmente à identificação das Condições de Produção do Discurso e das Formações Ideológicas que representam a estrutura sócio ideológica de uma formação social. Elas dão sustentação ao dizer, produzindo sentidos que discursivamente procuram camuflar conflitos, deixando passar a ideia de ausência de contradições de classe. Há que se considerar também que o sujeito, ao produzir um discurso, o faz, a partir de um lugar social, de uma posição ideológica com a qual se identifica.

Além dessas categorias, é necessário levar em consideração que todo discurso concreto é marcado pela alteridade, pela historicidade, ou seja, traz em si a presença do outro, no entrelaçamento de vários discursos, provindos de outro lugar anterior que abre possibilidades para novos efeitos de sentido. A esse lugar anterior, onde estão os "já ditos", ${ }^{2}$ prontos a serem convocados, a AD denomina memória discursiva, como um lugar de retorno a outros discursos, não como repetição, mas como ressignificação.

A memória discursiva envolve uma relação da linguagem com a história e pensá-la requer observar as relações conflituosas dos aspectos de historicidade com os processos da linguagem. Para Courtine ( 198 I , p. 53), o termo memória designa algo distinto de qualquer lembrança ou memorização psicológica: "a noção de memória discursiva diz respeito à existência histórica do enunciado no seio de práticas discursivas, reguladas pelos aparelhos ideológicos".

Nesse compasso, cabe a observação feita por Indursky (2009, p. 6): "quando a repetição se dá com deslizamento dos sentidos, este deslizamento vem, nas palavras de Pêcheux (1988, p. 52) 'perturbar a memória"'. Essa quebra da repetibilidade estabelece uma nova forma de repetição e, por consequência, promove uma reorganização da memória social, de modo a acomodar os novos sentidos.

É a memória discursiva que ressoa no deslizamento de sentidos, constituindo-se como uma "presença-ausente" na ressignificação.Avançando nessa discussão, chegamos ao funcionamento da memória discursiva. Ainda segundo Indursky (2009, p. 8),

[...] é em função dela [da memória discursiva] que certos sentidos são 'esquecidos', ou seja, certos sentidos que em um determinado momento podiam ser produzidos no seio de uma FD, em função de mudanças conjunturais, não podem mais ser ditos, atualizados, lembrados.

No entanto, é importante considerar que essa interdição ocorrida na memória discursiva não implica o completo apagamento. Com isso, é possível que os sentidos fiquem recalcados e possam ser recuperados no mesmo ou em outro momento histórico (INDURSKY, 2009). É disso que trataremos no próximo tópico.

\footnotetext{
${ }^{2}$ Noção desenvolvida por Pêcheux (1988), que remete "a uma construção anterior, exterior".
} 


\section{TRABALHO DOCENTE: “ENGAJAMENTO ESPIRITUAL” E "COMPROMISSO COM A EDUCAÇÃO"}

A partir dessas reflexões, anteriormente esboçadas, passaremos a seguir à análise de algumas materialidades discursivas acerca do trabalho do professor. Neste trabalho, tomamos como materialidades discursivas para análise dois editoriais. O primeiro, do jornal "Gazeta de Alagoas", publicado em 21 de julho de 20 I0, denominado Desaprendizado Real, tece comentários sobre os maus resultados das escolas públicas de Alagoas no ENEM de 20 I0. O segundo, do jornal "O Globo", publicado no dia 02 de setembro de 2013 e intitulado "Além do Corporativismo", repercute a greve dos professores das redes estadual e municipal do Rio de Janeiro ocorrida em 2013, a qual se estendeu de agosto a outubro daquele ano. Eis, a seguir, a primeira sequência discursiva, do editorial do jornal alagoano.

SDI: Como um casamento pecaminoso, têm se conjugado com invulgar recorrência a ausência de estratégias inovadoras e de investimentos mais ousados por parte do poder público e a inclemência de longuíssimas e inconsequentes greves implementadas pelas entidades representativas do magistério. [...]

Considerando as condições de produção estritas, cabe ressaltar que se trata do período que antecede as eleições estaduais e federais de 2010, momento também em que se encerrava uma greve dos trabalhadores da educação de Alagoas. Ao mesmo tempo, era divulgado pelo INEP o mau resultado das escolas públicas estaduais alagoanas no Exame Nacional do Ensino Médio. Tal conjuntura leva o jornal a se posicionar por meio de editorial.

Inicialmente, observamos, na materialidade, o atravessamento do discurso religioso, constituindo um recurso metafórico. A figura do "casamento pecaminoso" associando a ausência de ações governamentais e as greves do magistério que funcionam como forma de apresentar governo e professores, como responsáveis pelo fracasso da educação em Alagoas.

Matrimônio e pecado são invocados da memória discursiva religiosa e ressignificados, objetivando caracterizar pejorativamente os movimentos grevistas dos professores. $\bigcirc$ deslizamento de sentidos da docência para um viés negativo ocorre, à medida que são igualados governo e professores. Observa-se aqui o retorno da memória de discursos outros que caracterizam o magistério como sacerdócio, vocação, razão pela qual o casamento entre os dois (governo e magistério) é pecaminoso. Estar em greve não se coaduna com os sentidos predominantes de missão/vocação. Indursky (2009, pp. 8-9) corrobora essa afirmação quando diz que "é a memória discursiva que ressoa no deslizamento de sentidos". Ou seja, mediante o movimento do interdiscurso, sentidos recalcados são recuperados em outro momento histórico. (INDURSKY, 2009). 
O interdiscurso é o movimento de interrelação das formações discursivas que possibilita ao sujeito enunciador a apropriação de elementos da memoria que fornecem, como diz Courtine (1999, p. 20), "sob a forma de citação, recitação ou pré-construído os objetos do discurso em que a enunciação se sustenta".

O funcionamento do discurso da vocação/missão continuará se materializando na continuidade da sequência, quando é apontada a "inclemência" das greves dos professores. Novamente, a falta de clemência, de compaixão são mais alguns componentes semânticos que divergem do discurso de exaltação do professor, que detém em sua construção histórica, como vimos inicialmente, os sentidos de vocação, abnegação, sacerdócio. Esse mesmo discurso é acionado na próxima sequência.

SD2: [...] Para equacionar esse grave problema é necessária a junção de esforços do poder público e de todo o magistério. Infelizmente, hoje, a questão é maior que a mera destinação de recursos para o segmento. Mais verbas e maior inteligência em sua aplicação é condição sine qua non para a correta abordagem do dilema, mas tamanha é a tragédia que algo mais precisa se somar a item material de primeira necessidade. Este algo mais é um engajamento superior, espiritual, do magistério, conformando um novo compromisso, tão inovador que seja capaz de vencer os limites do corporativismo. Sem essa união, noves fora nada: Alagoas seguirá vítima da deseducação.

Como dito anteriormente, a materialidade discursiva mantém certa linearidade argumentativa, ao continuar associando o magistério ao governo, desta feita para apontar o que seria a solução do grave problema educacional vivido por Alagoas: da parte do governo, maior investimento e "maior inteligência em sua aplicação" e, da parte dos professores, "um engajamento superior, espiritual".

Como se pode notar, de forma mais destacada, (re)surge o discurso do magistério missional e vocacional, uma vez que, da memória discursiva, reaparece o caráter espiritual da atividade do professor, arraigado, como já vimos anteriormente, em nossa formação social e no processo de constituição do trabalho docente no Brasil. É a retormada desses sentidos da memória discursiva por meio do interdiscurso que permite o movimento de retorno e atualiza o já-dito.

No polo antagônico a esse engajamento espiritual encontram-se, necessariamente, os movimentos reivindicatórios, as greves. Esses movimentos não coadunam com a atuação heroica do professor que, a despeito das intempéries, dificuldades financeiras e precariedade de trabalho, deverá superar o "corporativismo" de sua classe e a rejeição.

Desse modo, encontramos a retomada do discurso sobre a missão do professor, constituído na memória discursiva. Essa "ausência presente" que encontramos na materialidade analisada pode ser ilustrada e/ou explicada também da seguinte forma por Marx (2006, p. 203).

Os homens fazem sua própria história, mas não a fazem como querem; não a fazemsob circunstâncias de sua escolha e sim sob aquelas com que se defrontam diretamente, ligadas e transmitidas pelo passado. A tradição de todas as gerações mortas oprime como um pesadelo o cérebro dos vivos. E justamente quando parecem empenhados em revolucionar-se a si e às coisas, em criar algo que jamais existiu, precisamente nesses períodos de crise revolucionária, os 
homens conjuram ansiosamente em seu auxílio os espíritos do passado, tomando-lhes emprestado os nomes, os gritos de guerra, as roupagens, a fim de apresentar a nova cena da história do mundo nesse disfarce tradicional e nessa linguagem emprestada.

Dessa forma, no intuito de propor o "novo" para solucionar os problemas da educação no estado, o sujeito traz o "velho" discurso do compromisso com a educação, da missão do professor, o qual foi constituído no percurso histórico da educação no Brasil. Esse mesmo discurso encontra-se materializado nas sequências discursivas do editorial "Além do Corporativismo", do jornal "O Globo". Também aí constatamos os retornos e o funcionamento de sentidos que caracterizam a docência como missão/vocação. Vejamos a sequência que segue.

SD3: Professores públicos do Rio voltaram a paralisar as atividades em sala de aula[...], numa greve pautada, mais uma vez, por reivindicações salariais [...] Mobilizar-se por melhoria de vencimentos está entre os direitos assegurados a todos os trabalhadores. Mas a constância com que o magistério recorre a greves para pressionar o poder público a abrir o cofre leva à inescapável conclusão de que algo está fora de ordem em movimentos que, pontualmente, tomam os alunos como reféns das paralisações, restringindo-lhes o direito à educação.

Debruçando-nos sobre o contexto imediato da formulação desses dizeres, deparamonos com o ano de 2013, o qual marca um período difuso de efervescência política no Brasil, com uma série de manifestações de rua convocadas pelas redes sociais na internet e contrárias ao governo da presidente Dilma Rouseff.

Ao mesmo tempo, o editorial refere-se à greve dos professores das redes municipal e estadual do Rio de Janeiro, ocorrida no período de agosto a outubro de 2013. Esse movimento reivindicatório foi marcado por embates renhidos entre os governos carioca e fluminense e os trabalhadores: a retirada à força de professores da câmara municipal; brigas de docentes entre si e com supostos pais de alunos; corte de ponto levado à efeito pela prefeitura; judicialização; audiência de conciliação com o ministro do STF Luiz Fux, etc.

De sua formação ideológica e discursiva o sujeito produz seu dizer e materializa o mesmo discurso que visualizamos nos excertos da "Gazeta de Alagoas". Encontramos aqui uma série de expressões parafrásticas relacionadas à redundância as quais conduzem o leitor ao entendimento de que as greves do magistério são constantes e intercorrentes. Ao mesmo tempo, explicita-se que o objetivo das greves restringe-se unicamente a ganhos financeiros, embora sejam citadas outras pautas.

Na continuidade, temos uma interessante imagem metafórica de um sequestro, na qual o professor é o sequestrador, os alunos os reféns e o governo a vítima extorquida. "Mas a constância com que o magistério recorre a greves para pressionar o poder público a abrir o cofre leva à inescapável conclusão de que algo está fora de ordem em movimentos que, pontualmente, tomam os alunos como reféns das paralisações, restringindo-lhes o direito à educação".

Tal cena procura não apenas demonstrar a incompatibilidade da greve com a profissão docente, como também associá-la a um crime contra os alunos. Mais uma vez o antagonismo entre as paralisações 
e a figura do professor é revelador do discurso objeto de nossa análise, ou seja, ser professor e estar nas ruas e não na sala de aula não é condizente com a missão.

É do mesmo editorial a próxima sequência discursiva.

SD4: Lutar, na prática, por melhorias salariais epidérmicas empobrece a agenda do magistério, cujo compromisso com a Educação precisa avançar além do horizonte raso dos interesses corporativos.

Mais uma vez a memória discursiva é acionada pelo movimento do interdiscurso e traz à tona o pré-construído "compromisso com a educação". Ressoam aí todos os sentidos já cristalizados e amalgamados sobre o papel do docente e sua identidade: o professor "sacerdote", a "professora mãe", o "regenerador", etc. Tal "compromisso" leva, assim como no editorial da "Gazeta de Alagoas", ao inescapável desligamento entre o docente e sua classe, sob pena de incorrer no corporativismo e no egoísmo e contrariar os sentidos já definidos para sua profissão/missão.

Como vimos anteriormente, o engajamento dos professores entre si, melhor dizendo, a compreensão de que compõem uma categoria trabalhadora é algo recente para o magistério brasileiro e adveio justamente da ampliação/precarização do seu trabalho. É sabido que os primeiros sindicatos de trabalhadores da educação datam de fins da década de 1980 e que, antes disso, a própria sindicalização de professores era proibida. Outrossim, pelo discurso que estamos evidenciando, materializado nos editoriais e arraigados em nossa formação social, a greve será caracterizada, de fato, como atitude egoísta, corporativista e incompatível com a profissão de professor.

Como se pode notar, de forma mais destacada, (re)surge a memória do discurso religioso do magistério missional e vocacional, arraigado, como já vimos anteriormente, em nossa formação social e no processo de constituição do trabalho docente no Brasil. A aparição desses sentidos da memória discursiva por meio do interdiscurso permite o movimento de retorno e atualiza o já-dito. Em outras palavras, o binômio educação/religião presente em nossa história é retomado. Na batalha travada entre os interesses materiais de sua classe e o exercício de sua missão, o docente, mediante um engajamento espiritual, (desprovido de interesses materiais) "vencerá o corporativismo" e derrotará a deseducação e os maus resultados, a partir do momento em que retomar seu papel para o qual foi vocacionado. Ou seja, é a atuação heroica do professor, a despeito das intempéries, dificuldades financeiras e precariedades de trabalho, que possibilitará a superação do "corporativismo" de sua classe.

No polo antagônico a esse engajamento espiritual encontram-se, necessariamente, os movimentos reivindicatórios, as greves, a necessidade de engajamento político do professor, junto a outras categorias de trabalhadores, na luta por melhores condições de trabalho, por uma educação pública de qualidade socialmente referenciada para todos. A materialidade mantém certa linearidade argumentativa ao continuar associando o magistério ao governo, desta feita para apontar o que seria a solução do grave problema 
educacional vivido por Alagoas: da parte do governo, maior investimento e "maior inteligência em sua aplicação" e, da parte dos professores, "um engajamento superior, espiritual". Sobre essa questão, Dias (2009, p. 38) assim se posiciona: "Então era preciso expropriar a subjetividade desta classe, capturar o seu conhecimento e transformá-lo em conhecimento do capital".

Por meio desse apelo ao engajamento, chegamos ao ponto de encontro entre os sentidos sobre o professor sedimentados na memória discursiva e uma das características marcantes da reestruturação produtiva do Capital: a busca pela apreensão da subjetividade do trabalhador.

\section{CONSIDERAÇÕES FINAIS}

A educação e, por extensão, o trabalho do professor cumprem papéis sociais ao mesmo tempo contraditórios. Os dois podem ser instrumentos de reprodução da ordem social e potenciais agentes de transformação da sociedade. Contudo, não se pode negar que o caráter reprodutivo de ambos tem prevalecido, de modo especial na educação básica, em função das exigências do capital.

Nesse contexto, ao refletirmos sobre o trabalho do professor, desvelando o funcionamento de sentidos construídos historicamente e tidos, muitas vezes, como óbvios, estamos contribuindo para a compreensão da prática educativa e para um repensar sobre o que é, de fato, ser professor.

Na perspectiva da Análise do Discurso pecheutiana, ao produzir materialidades discursivas o sujeito o faz a partir de um lugar social, de uma posição ideológica com a qual se identifica. $\bigcirc$ discurso da missão/vocação docente, como vimos, materializado nos textos midiáticos atuais, convive (harmoniosamente ou não) com todas as propostas e alegações de uma educação posta como moderna, fundada na meritocracia, no tecnicismo e voltada para as necessidades do mercado, logo, do lugar da formação ideológica do capital. $\bigcirc$ que autoriza essa conclusão? A resposta nos foi dada, ao analisarmos as materialidades discursivas, quando nos deparamos com forms de apropriação da subjetividade do trabalhador, cada vez mais sofisticadas, que buscam fazer com que o professor sinta-se culpado pelo fracasso da educação.

Desse modo, o discurso que analisamos, residente no imaginário social e na memória discursiva é trazido à tona pelo interdiscurso nos textos jornalísticos analisados e constitui precisamente a forma de cooptação da subjetividade dos trabalhadores da educação e busca não apenas mantê-los em atividade sem interrupções, exercendo suas funções com dedicação "espiritual", provocando o conformismo nas relações de trabalho, ainda que isso lhe custe menos tempo para suas atividades pessoais e menos qualidade de vida, sob pena de estar prejudicando o futuro de seus alunos e do próprio país.

O professor é responsabilizado pelo fracasso das escolas públicas em exames nacionais e internacionais, ao mesmo tempo em que se censuram e até se criminalizam suas atividades de greve, de 
protesto ou de paralisação. Esse quadro discursivo tornou-se possível, como vimos, por meio de recuperações de sentido, apagamentos e silenciamentos, os dois últimos impedindo a insurgência de outros efeitos de sentido dissonantes da formação discursiva do sujeito que acabariam por enfraquecer o teor das argumentações, haja vista serem provenientes de outros espaços discursivos. Dessa forma, desacredita-se a compreensão de educação como transformadora; do professor como trabalhador proletarizado, pertencente a uma categoria que tem a greve como instrumento necessário de luta não apenas em favor dos professores, mas do conjunto da sociedade.

Finalmente, considerando o quadro atual de reformas e de desmonte de conquistas sociais, o qual demonstra o avanço e a consolidação do projeto neoliberal de Estado Mínimo, entendemos, com esta reflexão sobre a natureza do trabalho docente, poder contribuir para uma compreensão crítica que possibilite atitudes responsivas de sujeitos que sofrem as determinações sociais, mas têm indubitavelmente a possibilidade de construir o novo, de fazer história. Trata-se da possibilidade/necessidade de que o educador assuma seu papel transformador e seu lugar junto a seus pares como trabalhador, como sujeito de sua história.

\section{REFERÊNCIAS}

ALMEIDA, J S. de. Mulheres na educação: missão, vocação e destino? a feminização do magistério ao longo do século XX. in: ALMEIDA, J. S. de; SAVIANI, D.; SOUZA, R. F.; VALDEMARIN, V. T. O legado Educacional do século XX. 2 ed. Campinas, SP: Autores Associados, 2006.

AZEVEDO, F. A Cultura Brasileira: introdução ao estudo da cultura no Brasil. São Paulo, Edições Melhoramentos, 1958.

CARNEIRO, E. de A. Análise do Discurso: notas introdutórias(Apêndice), In: O Discurso Fundador do Acre: heroísmo e patriotismo no último oeste. Dissertação de Mestrado em Letras - Linguagem e Identidade, Departamento de Letras, UFAC, Rio Branco - Ac, 2008.

COSTA, Marisa Vorraber. Trabalho docente e profissionalismo. Porto Alegre: Sulina, 1995.

COURTINE, J-J. Análise do Discurso Político. Languages, n 62, junho, 1981.

DRUCK, G. Trabalho, Precarização e Resistências: novos e velhos desafios. Caderno CRH, Salvador, v. 24, n. spe 01, p. 37-57, 2011.

FERREIRA, M. C. L. O quadro atual da Análise de Discurso no Brasil. Porto Alegre, Correio da APPOA, 2005.

FLORÊNCIO, A.M.G.; Magalhães, B.R.; Cavalcante, M.S.A.O.; Silva Sobrinho, H.F. Análise do Discurso: fundamentos \& práticas. Maceió: EDUFAL, 2009.

INDURSKY, F. Memória, Interdiscurso: limites e contrastes. Porto Alegre, 2009. 
LOURO, G. L. Gênero, sexualidade e educação: uma perspectiva pós-estruturalista. 2. ed. Petrópolis, Rio de Janeiro: Vozes; 2008.

LUKÁCS, G. Para uma ontologia do ser social. v. II. Tradução de Nélio Schneider, Ivo Tonet e Ronaldo Vielmi Fortes. São Paulo: Boitempo, 2013.

MARX, K. O I 8 brumário de Luiz Bonaparte. São Paulo: Centauro, 2003.

MELO, Kátia Maria Silva de. Discurso, consenso e conflito: a (re)significação da profissão docente no Brasil. Maceió: Edufal, 20ll.

ORLANDI, E. P. Discurso e Texto. Campinas: Pontes, 2008.

PÊCHEUX, M. Semântica e discurso. Uma crítica à afirmação do óbvio. Tradução Eni SHIGUNOV NETO, A.; Maciel, L. S. B. O ensino jesuítico no período colonial. Educar, n. 31, p. I69- I89, 2008. Editora UFPR.

VOESE, I. O movimento dos sem-terra na imprensa: um exercício de análise de discurso. ljuí: Ed. UNIJUÍ, 1997.

VOLÓCHINOV, Valentin. Marxismo e filosofia da linguagem. São Paulo, Editora 34, 2017.

\section{COMO CITAR ESSE ARTIGO}

CAVALCANTE, Maria do Socorro Aguiar Oliveira; LIMA, José Edson Ferreira. O trabalho docente no discurso midiático: sentidos que retornam. Debates em Educação, Maceió, v. 12, n. 28, p. 365-382, Set./Dez. 2020. ISSN 2175-6600. Disponível em:

https://www.seer.ufal.br/index.php/debateseducacao/article/view/9868. Acesso em: dd mmm. aaaa. 